\title{
Gas exchange in massai grass under five nitrogen fertilization levels during establishment and regrowth ${ }^{1}$
}

\author{
Marcos Neves Lopes², Claudivan Feitosa de Lacerda², Magno José Duarte Cândido²*, \\ Roberto Cláudio Fernandes Franco Pompeu ${ }^{3}$, Rodrigo Gregório da Silva ${ }^{4}$, José Wellington \\ Batista Lopes ${ }^{2}$, Francisco Ronaldo Belém Fernandes ${ }^{2}$, Francisco Marcus Lima Bezerra ${ }^{2}$
}

\footnotetext{
1 Pesquisa financiada pelo MEC/SESU.

2 Universidade Federal do Ceará - UFC.

${ }^{3}$ Empresa Brasileira de Pesquisa Agropecuária, Centro Nacional de Pesquisa Caprinos e Ovinos.

${ }^{4}$ Instituto Federal de Educação, Ciência e Tecnologia - IFCE, Campus Avançado do Tauá.

* Pesquisador do CNPq e tutor do PET Zootecnia/UFC.
}

\begin{abstract}
The objective of this study was to evaluate gas exchange in the massai grass during establishment and regrowth cycles in a greenhouse, using five nitrogen $(\mathrm{N})$ fertilization levels. A completely randomized split-plot design of five nitrogen levels $\left(0 ; 150 ; 300 ; 450\right.$ and $600 \mathrm{mg} \mathrm{N} \cdot \mathrm{dm}^{-3}$ of soil) was employed with the $\mathrm{N}$ levels as plots, and the cycles (establishment, regrowth 1 and 2) as subplots, evaluated with five replicates. We evaluated leaf transpiration (E), leaf temperature (TFOL), leaf photosynthesis rate (A), leaf carbon dioxide concentration (Ci), stomatal conductance (gs), photosynthesis/transpiration ratio (A/E), photosynthesis/conductance ratio (A/gs), chlorophyll relative index (CRI), and nitrogen sufficiency index (NSI). Growth cycles influenced all physiological characteristics, except for NSI. N fertilization levels affected TFOL, A, CRI and NSI variables, whereas for gs, E, Ci, A/E and A/gs it did not occur. A increased from 6.38 to $10.33 \mu \mathrm{mol} \cdot \mathrm{m}^{-2} \cdot \mathrm{s}^{-1}$, at levels 0 and $600 \mathrm{mg} \mathrm{N} \cdot \mathrm{dm}^{-3}$ of soil, respectively. Gas exchange in the massai grass was favored by nitrogen fertilization, since the cycles amended these characteristics of the grass.
\end{abstract}

Key Words: chlorophyll, $\mathrm{CO}_{2}$ concentration, Panicum maximum, photosynthesis

\section{Introduction}

Tropical forage grasses belonging to the Panicum genus have a prominent place in the intensification of production systems on pasture. This is due to the relevant characteristics of this species, such as high tolerance to trampling, high yield, good nutritional value and high response to production factors. Among the species of the Panicum genus, massai grass derived from natural crossing between Panixum maximum $\times$ Panicum infestum is a promising forage option for farming, due to the small increase in stem elongation, to high tillering, high capacity for regrowth after cutting or grazing, the high leaf biomass, besides promoting excellent ground cover.

Photosynthetic activity of forage canopy responds to the availability of abiotic factors, constituting one essential characteristic for the expression of the potential biomass production of forage used. Among the nutrients, nitrogen is the most important, for its remarkable influence on the production increase in intensively managed forage, and it is an essential component of protein and chlorophyll, needed for the formation of thylakoids and enzymes, and thus assuming a key role in gas exchange between plant and environment. Carbon use in meristematic activities associated with morphogenic processes has shown high dependence on adequate nitrogen nutrition (Gastal et al., 1992).

Response from gas exchange in intensively managed forages under nitrogen fertilization is essential for the better understanding of how the process of forage production occurs, and for the establishment of fertilizer levels that represent the maximum biological efficiency of the plant. However, such studies are scarce, hence the conduction of the present study to evaluate gas exchange in Panicum maximum $\times$ Panicum infestum cv. Massai, during establishment and two regrowth cycles under five nitrogen fertilization levels in a greenhouse.

\section{Material and Methods}

This research was performed in a greenhouse from the Departamento de Fitotecnia of the Universidade Federal do Ceará (UFC), in Fortaleza city, Ceará State, in the period from June to December 2008. Fortaleza is located at an average altitude of $21 \mathrm{~m}$, South latitude $03^{\circ} 45^{\prime} 47^{\prime \prime}$, West longitude $38^{\circ} 31^{\prime} 23^{\prime \prime}$ and presents climate type Aw', rainy tropical, according to Köppen climate classification. The group 
recorded minimum and maximum temperatures daily, with mean values of 25.8 and $40.5^{\circ} \mathrm{C}$ (establishment), 25.6 and $40.6^{\circ} \mathrm{C}$ (regrowth 1 ), 25.9 and $40.9^{\circ} \mathrm{C}$ (regrowth 2 ), respectively.

Treatments were evaluated according to completely randomized split-plot design with time repeated measures. Nitrogen fertilization levels $(0 ; 150 ; 300 ; 450$ and $600 \mathrm{mg}$ $\mathrm{N} . \mathrm{dm}^{-3}$ of soil) were the plots, and the growth cycles (three growth cycles: establishment with 43 days and regrowth, with 1 and 2 with 28 days, respectively) were the subplots, with five replicates, totaling 25 experimental units.

The soil used in the experiment was Yellow Ultisol. After collected, the soil was sieved for better homogenization and retention of coarse materials. Soil samples related to $0-20 \mathrm{~cm}$-deep layer presented the following chemical composition: $4 \mathrm{mg} \cdot \mathrm{dm}^{-3}$ of $; 76 \mathrm{mg} \cdot \mathrm{dm}^{-3}$ of $; 2.0 \mathrm{cmol}_{c} \cdot \mathrm{dm}^{-3}$ of $\mathrm{Ca}^{2+} ; 1.9 \mathrm{cmol}_{\mathrm{c}} \cdot \mathrm{dm}^{-3}$ of $\mathrm{Mg}^{2+} ; 0.0 \mathrm{cmol}_{\mathrm{c}} \cdot \mathrm{dm}^{-3}$ of $\mathrm{Al}^{3+}$; $11 \mathrm{mg} \cdot \mathrm{dm}^{-3}$ of $\mathrm{Na}^{+} ; 9.10 \mathrm{~g} \bullet \mathrm{kg}^{-1}$ of organic matter; SB $4.14 \mathrm{cmol}_{\mathrm{c}} \cdot \mathrm{dm}^{-3}$; CTCt $4.14 \mathrm{cmol}_{\mathrm{c}} \cdot \mathrm{dm}^{-3} ; \mathrm{pH}$ in water of 5.7; $19 \mathrm{ppm}$ of $\mathrm{Fe}^{2+} ; 0.14 \mathrm{mg} \bullet \mathrm{dm}^{-3}$ of $\mathrm{Cu}^{2+} ; 3.91 \mathrm{mg} \bullet \mathrm{dm}^{-3}$ of $\mathrm{Zn}^{2+}$ and $12.18 \mathrm{mg} \cdot \mathrm{dm}^{-3}$ of Mn. For the fertilization, we followed the recommendation of CFSEMG (1999) for levels suggested for grasses with high yield potential and high yield level.

Pots were randomly distributed inside the greenhouse. At the moment of filling the pots with capacity of $10 \mathrm{dm}^{3}$ each, we performed soil amendment, applying a dose of limestone of 6.169 g.pot ${ }^{-1}$, equivalent to $1,233 \mathrm{~kg} \cdot \mathrm{ha}^{-1}$, according to the fertility analysis, aiming at the increase of calcium content and in the $\mathrm{pH}$ value. During a period of ten days, the samples received daily irrigation, in order to speed up the reaction of lime.

The control of daily irrigation to be applied was done by installing mercury tensiometers $(\mathrm{Hg})$ in the pots (two tensiometers per treatment), with water replacement when mercury column (h) reached about $10.0 \mathrm{~cm} \mathrm{(} \psi_{\mathrm{m}}$ around $-7.98 \mathrm{kPa}$ ) in the treatments supplied with higher levels of nitrogen. The treatment that received the level of $600 \mathrm{mg}$ $\mathrm{N} . \mathrm{dm}^{-3}$ of soil was the reference for the water replacement applied in the other treatments, according to the equation: $\psi_{\mathrm{m}}=-12.6 \mathrm{~h}+\mathrm{h}_{1}+\mathrm{z}$; where: $\psi_{\mathrm{m}}=$ matric potential in $\mathrm{cm}$ of water column; $h=$ height of mercury column $(\mathrm{Hg})$ in the gauge in $\mathrm{cm} ; \mathrm{h}_{1}=$ height of the $\mathrm{Hg}$ level in the gauge in $\mathrm{cm}$, in relation to the soil surface and $\mathrm{z}=$ depth of the porous cup in $\mathrm{cm}(10 \mathrm{~cm})$ (Amaro Filho et al., 2008). At the end of irrigation, we registered the $\mathrm{Hg}$ column height in the gauge $(\mathrm{cm})$, which is presented with $5.0 \mathrm{~cm}\left(\psi_{\mathrm{m}}\right.$ around $\left.-1.80 \mathrm{kPa}\right)$ for all treatments, i.e., the soil moisture conditions were kept near field capacity in all experimental units.
Sowing was carried out using an average of 50 seeds per pot. Pre-thinning was done eight days after emergence, maintaining 12 plants per pot, which were reduced to three after final thinning, 13 days after emergence.

Three cuts were done: the first for uniformity, which had the horizontal length of the pseudostem as reference, i.e., all potted plants were cut, remaining only a residue with $10 \mathrm{~cm}$ length of stem, 43 days after seedling emergence. This criterion was adopted aiming to standardize the cut plants, since it presented the growth with different inclination angles of the tiller, impairing the cut uniformity, if the cut were done at fixed vertical height. The second and third cuts followed the same criterion and were accomplished after a rest period of 28 days.

Fertilizations of phosphate (simple superphosphate), potassium (potassium chloride) and micronutrients (FTE BR-12) were done according to the results of soil analysis, as well as the use of limestone. The applications of nitrogen (urea) and potassium were splitted. At establishment cut, the nitrogen dose for each treatment was divided into two: the first half applied soon after final thinning, and the second half after 14 days. In all nitrogen applications we made the urea dilution in water used for irrigation for better standardization at the application of this fertilizer. Potassium was made available in the two applications, the first (120 mg $\cdot \mathrm{dm}^{-3}$ of $\left.\mathrm{K}_{2} \mathrm{O}\right)$ accomplished at the sowing. The second potassium application $\left(120 \mathrm{mg} \cdot \mathrm{dm}^{-3}\right.$ of $\left.\mathrm{K}_{2} \mathrm{O}\right)$ via aqueous solution was done soon after the uniformity cut, along with the first nitrogen dose at regrowth 1. Phosphorus' supply $\left(125 \mathrm{mg} \cdot \mathrm{dm}^{-3}\right.$ of $\mathrm{P}_{2} \mathrm{O}_{5}$ ) was given once at the time of sowing. At this moment, micronutrients $\left(25 \mathrm{mg} \cdot \mathrm{dm}^{-3}\right.$ of FTE BR-12) were also provided. The second half of the nitrogen dose for each treatment applied at regrowth 1 was released in the middle of rest period (28-day cycles). At regrowth 2, the same management was followed.

For the evaluation of gas exchange accomplished before cutting the forage, we used an infrared $\mathrm{CO}_{2}$ analyzer ("Infrared Gas Analyzer - IRGA", model LCI BioScientific). At each experimental unit (pot) we chose a newly-expanded leaf to make the measures on the median portion of the leaf, always between 9 and 11 a.m. At the moment of the readings, soil presented moisture content near field capacity.

Examined variables were: leaf transpiration rate $\left(\mathrm{E}, \mu \mathrm{mol} \cdot \mathrm{m}^{-2} \cdot \mathrm{s}^{-1}\right)$; leaf temperature $\left(\mathrm{TFOL},{ }^{\circ} \mathrm{C}\right)$; leaf photosynthesis rate $\left(\mathrm{A}, \mu \mathrm{mol} \cdot \mathrm{m}^{-2} \cdot \mathrm{s}^{-1}\right)$; leaf carbon dioxide concentration $(\mathrm{Ci}, \mathrm{ppm})$; stomatal conductance (gs, $\mu \mathrm{mol} \cdot \mathrm{m}^{-2} \cdot \mathrm{s}^{-1}$ ); photosynthesis/transpiration ratio (A/E, water use efficiency) and photosynthesis/conductance ratio (A/gs, intrinsic water use efficiency). 
Relative chlorophyll index (RCI) was measured with a chlorophyll meter (SPAD-502) on the day before the cut, at regrowths 1 and 2, at the same hour and always on the same leaf of other physiological evaluations, making five readings in the newly-expanded leaf from each plant of the experimental unit (pot), in the morning between 9 and 11 a.m.

Nitrogen sufficiency index (NSI) was calculated as the ratio between the average of measures of the chlorophyll meter in the leaves of the treatments (MCT) and the average in plants that received the highest dose (MCR) considered as the reference area $(\mathrm{NSI}=(\mathrm{MCT} / \mathrm{MCR}) \times 100)$ by having greater likelihood of no nitrogen deficiency and providing the maximum chlorophyll concentration in the leaves.

Data were submitted to analysis of variance, mean comparison test and regression analysis. The interaction between nitrogen fertilization $\mathrm{x}$ growth cycles was deployed by F-test, when significant $(\mathrm{P}<0.05)$. Growth cycles were compared by Tukey's test $(\mathrm{P}>0.05)$. The effect of fertilizer levels was evaluated through regression analysis, in the main effect when there was no interaction, or in the conditioning effect when this occurred. The choice of the models was based on the significance of linear and quadratic coefficients, through the Student's t test $(\mathrm{P}<0.05)$ and on the coefficient of determination. As assistance tool for statistical analyses, we adopted the procedures MIXED and GLM, of SAS statistical software (SAS Institute, 2003), according to the following mathematical model:

$$
Y i j k=\mu+\alpha i+\delta i j+\beta k+(\alpha \beta) i k+\varepsilon i j k
$$

where: Yijk $=$ observation relative to the $\mathrm{i}$ of nitrogen fertilization on $\mathrm{j}$ repetition in $\mathrm{k}$ cycle; $\mu=$ general average; $\alpha i=$ effect of level $i$ of nitrogen fertilization that is in the plot; $i=1,2,3,4,5$ levels of nitrogen fertilization; $\delta i j=$ error of the plot that received the i level of nitrogen fertilization on $\mathrm{j}$ repetition, defined as residual (a) $\mathrm{j}=1,2,3,4,5$ pots; $\beta \mathrm{k}=$ effect of $\mathrm{k}$ cycle that is in the subplot; $\mathrm{k}=1,2,3$ cycles; $(\alpha \beta) i k=$ interaction of factors (nitrogen fertilization levels $\times$ growth cycles; i fertilization level with the $\mathrm{k}$ cycle; $\varepsilon i j k=$ experimental error associated with Yijk; used as residual at subplots level, defined as residual (b).

\section{Results and Discussion}

There was no interaction $(\mathrm{P}>0.05)$ between nitrogen levels and growth cycles to the stomatal conductance (gs), or effects of nitrogen levels $(\mathrm{P}>0.05)$ on this variable, with average of $1.33 \mu \mathrm{mol} \cdot \mathrm{m}^{-2} \cdot \mathrm{s}^{-1}$. Stomatal conductance only differed $(\mathrm{P}<0.05)$ between growth cycles (Table 1$)$, reaching higher value $\left(3.79 \mu \mathrm{mol} \cdot \mathrm{m}^{-2} \cdot \mathrm{s}^{-1}\right)$ in regrowth 1 . The stomatal sensitivity to opening and closure is altered during the day course and, depending on the activity, development and adaptation of the plant. Quantity, distribution, size, shape and mobility of stomatal apparatus are characteristics of a species, which can be changed as a function of adaptations to local conditions, and may even vary from individual to individual (Larcher, 2006).

Thus, considering that under stress situations there is high heterogeneity in stomatal opening, the results above for the gs in regrowth 1 may have been a consequence of the disturbance caused by the first defoliation, leading to greater tillering from the basal buds, with increase in water demand (data not shown), resulting in greater stomatal opening as a mechanism to meet the $\mathrm{CO}_{2}$ absorption from external environment (Kuwahara \& Souza, 2009) and regulate the leaf temperature through transpiration (Slatyer, 1967).

No interaction ( $\mathrm{P}>0.05)$ was observed (between nitrogen levels and cycles) for the leaf transpiration, which was higher $(\mathrm{P}<0.05)$ at regrowth $1\left(11.41 \mu \mathrm{mol} \cdot \mathrm{m}^{-2} \cdot \mathrm{s}^{-1}\right)$ and without response $(\mathrm{P}>0.05)$ with the increase in nitrogen levels (Table 1). Despite the absence of effect $(\mathrm{P}>0.05)$ to leaf transpiration with increasing nitrogen levels, the gross value of this variable presented an increase trend $(\mathrm{P} \leq 0.5156)$ as nitrogen levels were raised, possibly due to increase in leaf production, leading to increase in the net canopy photosynthesis (Table 1) and consequently in water demand by the plants with higher water absorption by the roots (Yin et al., 2009). This effect possibly is due to greater enzymatic activity and may have increased the water absorption rate by the roots and the stomatal opening rate.

Higher leaf transpiration rate verified for the regrowth 1 possibly occurred through the superior $\mathrm{Ci}$ in this growth cycle (Table 1) in relation to the others, since the plant, in order to absorb $\mathrm{CO}_{2}$ from the external environment, inevitably loses water, due to the greater stomatal opening; however when this loss is reduced there is also constraint of $\mathrm{CO}_{2}$ input, which was observed at regrowth 2, presenting lower transpiration and as consequence reduction in $\mathrm{Ci}$ (Table 1), indicating interdependence between $\mathrm{CO}_{2}$ assimilation and water consumption (Larcher, 2006).

Leaf photosynthesis rate $(\mathrm{A})$ increased $(\mathrm{P}<0.05)$ with the increasing nitrogen levels and was higher and lower $(\mathrm{P}<0.05)$ at regrowth 2 and $1\left(10.21 \mu \mathrm{mol} \cdot \mathrm{m}^{-2} \cdot \mathrm{s}^{-1}\right.$ and $6.70 \mu \mathrm{mol} \cdot \mathrm{m}^{-2} \cdot \mathrm{s}^{-1}$, respectively), without interaction $(\mathrm{P}>0.05)$ between the factors (Table 1$)$. The lower value verified at the first regrowth may be due to the cutting impact on the plant, by the stress caused during growth with influence on photosynthesis, ratified by the effects observed on the morphogenic parameters of the grass in this growth cycle, like the increase in the phyllochron 
(reduction in leaf appearance rate) and reduction in the leaf elongation rate (data not shown), since the defoliation stress induces changes and responses in the subsequent growth of forage canopy.

During regrowth 1 , forage probably presented an unconsolidated root system, less efficient on nutrient absorption, which may have influenced the chlorophyll content (Table 2), consequently reducing the forage photosynthesis rate in this growth cycle. The lower photosynthesis rate to the growth during regrowth 1 probably resulted from the lower chlorophyll content in the leaf verified in this growth cycle, since this pigment is the main receptor of photosynthesis radiation and the deficiency in leaf generates considerable decrease in photosynthesis rate (Taiz \& Zeiger, 2009).

Regarding only the fertilization effect on photosynthesis rate, we observed increasing linear response $(\mathrm{P}<0.05)$, with values estimated at 6.38 and $10.33 \mu \mathrm{mol} \cdot \mathrm{m}^{-2} \cdot \mathrm{s}^{-1}$ for 0 and $600 \mathrm{mg} \mathrm{N} \cdot \mathrm{dm}^{-3}$ of soil, respectively (Table 1 ). For each milligram of $\mathrm{N} \cdot \mathrm{dm}^{-3}$ added, the leaf photosynthesis rate increased by $0.0066 \mu \mathrm{mol} \cdot \mathrm{m}^{-2} \cdot \mathrm{s}^{-1}$. For this variable, there was an increase of $61.9 \%$ for the level of $600 \mathrm{mg} \mathrm{N} \cdot \mathrm{dm}^{-3}$ in relation to its absence. This nitrogen effect favoring the photosynthesis is due to greater stimulation of enzyme

Table 1 - Effect of nitrogen fertilization on the physiology of the primary tiller of Panicum maximum $\times$ Panicum infestum cv. Massai during three growth cycles (establishment, regrowth 1 and regrowth 2)

\begin{tabular}{|c|c|c|c|c|c|c|c|}
\hline \multirow[t]{2}{*}{ Cycle } & \multicolumn{6}{|c|}{ Level $\left(\mathrm{mg} \mathrm{N} \cdot \mathrm{dm}^{-3}\right.$ of soil) } & \multirow[t]{2}{*}{ Equation } \\
\hline & 0 & 150 & 300 & 450 & 600 & Mean & \\
\hline \multicolumn{8}{|c|}{ Stomatal conductance $\left(\mathrm{gs}, \mu \mathrm{mol} \cdot \mathrm{m}^{-2} \cdot \mathrm{s}^{-1}\right)$} \\
\hline Regrowth 1 & 3.54 & 3.52 & 3.63 & 4.54 & 3.70 & $3.79 \mathrm{~A}$ & \\
\hline Regrowth 2 & 0.100 & 0.096 & 0.140 & 0.132 & 0.120 & $0.118 \mathrm{~B}$ & \\
\hline \multicolumn{8}{|c|}{ Leaf transpiration rate $\left(\mathrm{E}, \mu \mathrm{mol} \cdot \mathrm{m}^{-2} \cdot \mathrm{s}^{-1}\right)$} \\
\hline Regrowth 2 & 2.73 & 2.70 & 3.63 & 3.47 & 3.29 & $3.16 \mathrm{C}$ & \\
\hline \multicolumn{8}{|c|}{ Leaf photosynthesis rate $\left(\mathrm{A}, \mu \mathrm{mol} \cdot \mathrm{m}^{-2} \cdot \mathrm{s}^{-1}\right)$} \\
\hline Establishment & 5.61 & 6.22 & 9.21 & 9.82 & 9.97 & $8.17 \mathrm{~B}$ & $\hat{\mathrm{y}}=6.38+0.0066 * * \mathrm{~N} ; \mathrm{R}^{2}=0.32$ \\
\hline Regrowth 1 & 5.10 & 5.42 & 7.13 & 7.68 & 8.16 & $6.70 \mathrm{C}$ & \\
\hline Regrowth 2 & 8.35 & 8.06 & 11.67 & 12.22 & 10.75 & $10.21 \mathrm{~A}$ & \\
\hline \multicolumn{8}{|c|}{ Leaf temperature $\left(\mathrm{TFOL},{ }^{\circ} \mathrm{C}\right)$} \\
\hline Establishment & $45.1 \mathrm{Aa}$ & $45.3 \mathrm{Aa}$ & $44.8 \mathrm{Aa}$ & $44.7 \mathrm{Aa}$ & $44.8 \mathrm{Aa}$ & 44.9 & $\mathrm{Y}=44.92 \pm 0.80$ \\
\hline Regrowth 1 & $41.1 \mathrm{Ba}$ & $40.6 \mathrm{Ba}$ & $41.0 \mathrm{Ba}$ & $40.5 \mathrm{Ba}$ & $40.9 \mathrm{Ba}$ & 40.8 & $\mathrm{Y}=40.83 \pm 0.86$ \\
\hline Regrowth 2 & $46.6 \mathrm{Aa}$ & $43.8 \mathrm{Ab}$ & $43.1 \mathrm{Ab}$ & $39.5 \mathrm{Bc}$ & $39.2 \mathrm{Bc}$ & 42.4 & $\hat{\mathrm{y}}=46.23-0.0127 * * \mathrm{~N} ; \mathrm{R}^{2}=0.41$ \\
\hline
\end{tabular}

Table 2 - Effect of nitrogen fertilization on the physiology of the primary tiller of Panicum maximum $\times$ Panicum infestum cv. Massai during three growth cycles (establishment, regrowth 1 and regrowth 2)

\begin{tabular}{|c|c|c|c|c|c|c|c|}
\hline \multirow[t]{2}{*}{$\overline{\text { Cycle }}$} & \multicolumn{6}{|c|}{ Level $\left(\mathrm{mg} \mathrm{N} \cdot \mathrm{dm}^{-3}\right.$ of soil) } & \multirow[t]{2}{*}{ Equation } \\
\hline & 0 & 150 & 300 & 450 & 600 & Mean & \\
\hline \multicolumn{8}{|c|}{ Photosynthesis/Transpiration ratio (A/E) } \\
\hline Regrowth 1 & 0.45 & 0.48 & 0.62 & 0.67 & 0.73 & $0.59 \mathrm{C}$ & \\
\hline Regrowth 2 & 3.09 & 3.07 & 3.28 & 3.57 & 3.27 & $3.26 \mathrm{~A}$ & \\
\hline \multicolumn{8}{|c|}{ Photosynthesis/Conductance ratio (A/gs) } \\
\hline Regrowth 2 & 88.1 & 90.5 & 85.4 & 93.0 & 90.3 & $89.5 \mathrm{~B}$ & \\
\hline
\end{tabular}

$\mathrm{Y}=$ mean value and standard deviation.

Means followed by the same letters, in the same column (capital letter) are not different $(\mathrm{P}>0.05)$ by Tukey's test. 
activity and increased synthesis of the enzyme ribulose1,5-bisphosphate-carboxylase-oxygenase (RUBISCO), responsible for photosynthesis (Cabrera-Bosquet et al., 2009). Besides that, the higher photosynthesis observed at higher nitrogen levels is also due to increases, in both photochemical and biochemical phases. In the photochemical phase, probably there was an increase in light-gathering apparatus, as evidenced by the higher relative content of chlorophyll at higher nitrogen levels (Table 3 ). On the other hand, in the biochemical phase, the higher nitrogen levels may have favored a greater biosynthesis of proteins and enzymes related to photosynthesis (Taiz \& Zeiger, 2009).

For the internal $\mathrm{CO}_{2}$ concentration $(\mathrm{Ci})$, no interaction was recorded $(\mathrm{P}>0.05)$ between nitrogen level $\times$ growth cycle. This variable was not influenced $(\mathrm{P}>0.05)$ by the increase in nitrogen levels, with mean value of $237.33 \mathrm{ppm}$ (Table 1). Despite the absence of effect $(\mathrm{P}>0.05)$ verified for $\mathrm{Ci}$ with the raise in the nitrogen levels, the gross values presented a decreasing trend $(\mathrm{P} \leq 0.3209)$ with the increase in nitrogen levels, and can be ascribed to the greater activity of carboxylation enzymes at higher doses, favoring the carboxylation of organic molecules and reducing the concentration of free carbon dioxide in the mesophyll (Pan et al., 2004).

Internal $\mathrm{CO}_{2}$ concentration (Table 1) presented higher value (343.2 ppm) for the regrowth 1 , in comparison with the establishment (165.4 ppm) and regrowth 2 (203.4 ppm). The superiority in the $\mathrm{Ci}$ value at regrowth 1 is associated with the higher stomatal conductance in that growth cycle (Table 1), because the greater stomatal aperture favors higher absorption of $\mathrm{CO}_{2}$ from external environment (Lambers et al., 1998), evidencing that the stomatal resistance was not a limiting factor for the $\mathrm{CO}_{2}$ 's influx. Nevertheless, during the first growth at regrowth, plants received the stressful impact of uniformity cut and this may have led them to develop characteristics of stress status, as increase in respiration, release of stress hormones, photosynthesis inhibition, and growth disturbances, among others.

Therefore, the greater $\mathrm{Ci}$ in the regrowth 1 possibly made the plant direct a higher proportion of photoassimilates to the tillering after the intense cutting, in relation to the leaves, a fact evidenced by the lower photosynthesis rate in this cycle, stimulating the sprouting of basal buds, which was observed through the increase in the number of tillers, reduction in leaf elongation and in the number of living leaves per tiller (data not presented). Still, according to Alexandrino et al. (2005), after defoliation, the plant can change the pattern of assimilate partitioning.

We registered an interaction $(\mathrm{P}<0.05)$ between nitrogen levels $\times$ growth cycles (Table 1 ) for the leaf temperature (TFOL), which was higher $(\mathrm{P}<0.05)$ in the establishment than in regrowth 1 , not differing $(\mathrm{P}>0.05)$ from regrowth 2 in the absence and at lower nitrogen levels $(0 ; 150$ and $300 \mathrm{mg} \mathrm{N} \cdot \mathrm{dm}^{-3}$ of soil) and presenting similar values between the regrowth cycles at higher levels (450 and $600 \mathrm{mg} \mathrm{N} \cdot \mathrm{dm}^{-3}$ of soil). In the establishment and at the first regrowth, leaf temperature was not influenced $(\mathrm{P}>0.05)$ by increasing nitrogen levels, with average of 44.92 and $40.83^{\circ} \mathrm{C}$, respectively (Table 1). The lower leaf temperature in the regrowth 1 for the plants supplied with lower nitrogen levels in relation to the other cycles may be related to the higher rate of leaf transpiration, increasing the water demand by the plants (Bonfim-Silva et al., 2007) with higher water uptake by the roots, contributing to slow the leaf warming.

At the second regrowth we observed a linear decreasing effect $(\mathrm{P}<0.05)$ for the TFOL with increasing nitrogen levels, estimated at 46.23 and $38.61{ }^{\circ} \mathrm{C}$ for the levels of 0 and $600 \mathrm{mg} \mathrm{N} \cdot \mathrm{dm}^{-3}$ of soil, respectively. For each milligram of $\mathrm{N} \cdot \mathrm{dm}^{-3}$ added, leaf temperature was reduced in $0.0127^{\circ} \mathrm{C}$. Such reduction in TFOL possibly occurred in response to the behavior recorded in leaf transpiration rate (Table 1) with the increase in nitrogen fertilization, since transpiration is a primary controlling mechanism of leaf temperature,

Table 3 - Effect of nitrogen fertilization on the physiology of the primary tiller of Panicum maximum $\times$ Panicum infestum cv. Massai during two growth cycles (establishment, regrowth 1 and regrowth 2)

\begin{tabular}{|c|c|c|c|c|c|c|c|}
\hline \multirow[t]{2}{*}{ Cycle } & \multicolumn{6}{|c|}{ Level $\left(\mathrm{mg} \mathrm{N} \cdot \mathrm{dm}^{-3}\right.$ of soil) } & \multirow[t]{2}{*}{ Equation } \\
\hline & 0 & 150 & 300 & 450 & 600 & Mean & \\
\hline \multicolumn{8}{|c|}{ Chlorophyll relative index (CRI, SPAD unit) } \\
\hline Regrowth 2 & 19.42 & 20.98 & 24.04 & 25.78 & 27.32 & $23.51 \mathrm{~A}$ & $\hat{\mathrm{y}}=17.55+0.013 * * \mathrm{~N} ; \mathrm{R}^{2}=0.53$ \\
\hline \multicolumn{8}{|c|}{ Nitrogen sufficiency index (NSI, \%) } \\
\hline Regrowth 1 & 65.79 & 79.30 & 88.51 & 91.58 & 100.00 & $85.04 \mathrm{~A}$ & $\hat{\mathrm{y}}=69.96+0.052 * * \mathrm{~N} ; \mathrm{R}^{2}=0.75$ \\
\hline
\end{tabular}


dissipating part of the energy coming from solar radiation (Slatyer, 1967; Hopkins, 1999).

No interaction $(\mathrm{P}>0.05)$ between the factors (Table 2) was observed regarding the photosynthesis/transpiration ratio (A/E), which represents the instantaneous water use efficiency (WUE) and expresses quantitatively the momentary behavior of gas exchange in the leaf. Also we did not detect effect $(\mathrm{P}>0.05)$ of nitrogen fertilization on this variable, with average of 1.94; however we verified higher value $(\mathrm{P}<0.05)$ in regrowth 2 and a lower one in regrowth 1 (3.26 and 0.59), respectively (Table 2).

The lower value for the $\mathrm{A} / \mathrm{E}$ in the regrowth 1 is a result from reduced photosynthesis and increased leaf transpiration in this growth cycle. At regrowth 2, photosynthesis rate increased, and leaf transpiration decreased, providing an increase in the $\mathrm{A} / \mathrm{E}$ ratio, which represents a more efficient use of water (instantaneous WUE) in this grass growth cycle.

The superior response in WUE here reported for this cycle of growth (regrowth 2) of the forage can be attributed to the better structuring of the plant, with more consolidated root system and thus responding more efficiently to environmental factors (fertilization, radiation, temperature, air humidity). According to Larcher (2006), the efficiency in the use of water always changes when the conditions for the diffusion of $\mathrm{CO}_{2}$ or water are changed. When stomata are fully open, the $\mathrm{CO}_{2}$ uptake is more limited by the transfer resistance than the loss of water through transpiration. The best relationship between $\mathrm{CO}_{2}$ uptake and water loss is reached when stomata are partially closed, with the A/E ratio reaching higher values.

Concerning the photosynthesis/conductance ratio (A/gs) no interaction $(\mathrm{P}>0.05)$ was identified between the factors. This variable reached inferior and superior values $(\mathrm{P}<0.05)$ in regrowth 1 and at establishment, respectively (Table 2). As function of the higher $\mathrm{A} / \mathrm{gs}$ ratio during the forage establishment, the internal $\mathrm{CO}_{2}$ concentration decreased in this growth cycle (Table 1$)$. Furthermore, this variable (A/gs) was not influenced by the increasing nitrogen levels, with an average of 66.5 (Table 2).

The way the $\mathrm{CO}_{2}$ assimilation rate is related with stomatal conductance has ecological importance; if the $\mathrm{CO}_{2}$ assimilation and conductance vary proportionally and linearly, possibly the internal $\mathrm{CO}_{2}$ concentration $(\mathrm{Ci})$ and the efficiency in the use of water remain constant, in order to optimize gas exchange (Schulze \& Hall, 1982). In this study, although the internal $\mathrm{CO}_{2}$ concentration and stomatal conductance are superior in regrowth $1, \mathrm{~A} / \mathrm{E}$ and $\mathrm{A} / \mathrm{gs}$ ratios decreased during this growth cycle, indicating that stomatal conductance does not answer for the reduction in the efficiency of photosynthesis process efficiency in that growth cycle.

Chlorophyll relative index (RCI) examined during the growth of regrowth (regrowths 1 and 2) was influenced $(\mathrm{P}<0.05)$ by both nitrogen fertilization and growth cycles, but without significant interaction ( $\mathrm{P}>0.05)$ (Table 3$)$. An increase $(\mathrm{P}<0.05)$ was recorded for this variable when the first regrowth (19.39 SPAD units) was compared with the second (23.51 SPAD units) (Table 3). The superior value in regrowth 2 can be ascribed to the better structuring of the plant, with a more consolidated root system, exploring greater volume of soil and with higher capacity to uptake water and nutrients, resulting in greater chlorophyll content in the leaf during this growth cycle, as function of the best response to environmental factors (mainly nitrogen fertilization).

Nitrogen levels provided increasing linear response $(\mathrm{P}<0.05)$ for $\mathrm{CRI}$, with values estimated at 17.6 and 25.4 SPAD units to the levels of 0 and $600 \mathrm{mg} \mathrm{N} \cdot \mathrm{dm}^{-3}$ of soil, respectively (Table 3 ). In this variable, we observed an increase of $44.4 \%$ to the level of $600 \mathrm{mg} \mathrm{N} \cdot \mathrm{dm}^{-3}$ in relation to the absence of nitrogen fertilization. For each milligram of $\mathrm{N} \cdot \mathrm{dm}^{-3}$ added, CRI increased by 0.013 SPAD units. Increasing readings at the highest nitrogen levels, corresponding to higher levels of pigment in the leaf, justify the use of chlorophyll meter SPAD-502 as a tool to predict the initial emergence of nitrogen deficiency (Minolta Camera, 1989).

Although research using chlorophyll meter to generate information with tropical forage grasses is still limited (Colozza et al., 2000), for annual plants of economic interest (common bean, corn, cotton, among others) this determination (chlorophyll content determined by chlorophyll meter with the nitrogen concentration in the leaf) is promising for assessing the nutritional status of plants in relation to nitrogen participation (Silveira et al., 2003; Godoy et al., 2003; Argenta et al., 2001; Neves et al., 2005; Godoy et al., 2007).

For forage grasses, studies with the equipment Chlorophyll meter SPAD-502 (Soil Plant Analysis Development) are still scarce, but existing studies have already shown high correlation coefficient between instrument reading and nitrogen level (Santos, 1997). The author observed similar response pattern (high correlation) between the regrowth (first and second) of brachiaria grass. Abreu \& Monteiro (1999) developed a study with marandu grass, and found that for ages 28 and 42 days, SPAD values were significantly influenced by nitrogen levels of 205 and $314.5 \mathrm{mg} \cdot \mathrm{L}^{-1}$, respectively.

According to Abreu \& Monteiro (1999) the relationship between SPAD value and nitrogen concentration may be linear, until nitrogen is no longer assimilated and is 
accumulated in the form of nitrate, tending to form an intensity stabilization, reflecting the accumulation of nitrate.

Bullock \& Anderson (1998) assure that more chlorophyll is sinthetized with the increase of nitrogen availability for the plant, resulting in the increase of green intensity in the leaves. Meanwhile, this increase in the chlorophyll content reaches a level called photosynthesis maturity point, which remains unchanged even with increased levels of nitrogen in the plant tissue (Schepers et al., 1992; Costa et al., 2001). This fact was not verified in this study (Table 3), since the chlorophyll content responded linearly to nitrogen fertilization until the maximum level herein investigated $\left(600 \mathrm{mg} \mathrm{N} \bullet \mathrm{dm}^{-3}\right.$ of soil, equivalent to $1,200 \mathrm{~kg} \mathrm{~N} \cdot \mathrm{ha}^{-1} \cdot$ year $\left.^{-1}\right)$, i.e., there was no stabilization in the chlorophyll values at the highest levels of nitrogen.

When assessing marandu grass, Costa et al. (2008) found that the leaf chlorophyll content tended to stabilize from the level of $200 \mathrm{~kg} \mathrm{~N} \cdot \mathrm{ha}^{-1} \cdot$ year $^{-1}$. This shows the positive genetics of massai grass regarding the chlorophyll synthesis from the nitrogen availability, because the photosynthesis maturity point (Costa et al., 2001) of this grass is only achieved at high levels of nitrogen fertilizer, i.e., $600 \mathrm{mg} \mathrm{N} \cdot \mathrm{dm}^{-3}$ above the soil, as registered in this study.

The nitrogen sufficiency index (NSI), evaluated from the RCI and calculated by the relationship between the chlorophyll meter measure in massai grass plants, and the measure in the plants from the reference area (plants receiving higher nitrogen level, without $\mathrm{N}$ deficiency), is a non-destructive method to predict the nitrogen deficiency in the plant. No interaction was found $(\mathrm{P}>0.05)$ between the factors for the NSI that was similar $(\mathrm{P}>0.05)$ between the two regrowth cycles, but responding in an increasing linear way $(\mathrm{P}<0.05)$ to nitrogen levels, with values estimated at 69.96 and $101.16 \%$ to the levels 0 and $600 \mathrm{mg} \mathrm{N} \cdot \mathrm{dm}^{-3}$ of soil, respectively (Table 3 ). In this case, a clear difference is detected between the NSI of plants that did not receive nitrogen and of those that received the highest levels of nitrogen fertilization, indicating the deficiency of this nutrient in the absence of fertilization, and the suitable supply at higher nitrogen levels.

The nitrogen sufficiency index surpassed the critical threshold of $90 \%$ suggested by Hussain et al. (2000) in the dose estimated at $390 \mathrm{mg} \mathrm{N} \cdot \mathrm{dm}^{-3}$ of soil, indicating, according to adopted criterion, that the massai grass plants with fertilization supply superior to the equivalent level of $780 \mathrm{~kg} \mathrm{~N} \cdot \mathrm{ha}^{-1} \cdot$ year $^{-1}$ did not have their production limited by deficiency of this nutrient, as evidenced by the higher yield achieved by the plants fertilized with the highest nitrogen levels.

\section{Conclusions}

Physiological characteristics of massai grass are changed by the successive regrowth cycles and favored by the increase in nitrogen levels. The best response of nitrogen fertilization is achieved by applying $600 \mathrm{mg} \mathrm{N} \cdot \mathrm{dm}^{-3}$ of soil, equivalent to $1,200 \mathrm{~kg} \mathrm{~N} \cdot \mathrm{ha}^{-1} \cdot$ year $^{-1}$.

\section{Acknowledgements}

The authors thank SESu, especially the Programa de Educação Tutorial (PET) for granting financial support and scholarships.

\section{References}

ABREU, J.B.R.; MONTEIRO, F.A. Produção e nutrição do capimMarandu em função de adubação nitrogenada e estágios de crescimento. Boletim de Indústria Animal, v.56, p.137-146, 1999.

ALEXANDRINO, E.; GOMIDE, J.A.; GOMIDE, C.A.M Crescimento e desenvolvimento do dossel de Panicum maximum cv. Mombaça. Revista Brasileira Zootecnia, v.34, n.6, p.2164-2173, 2005.

AMARO FILHO, J.; ASSIS JÚNIOR, R.N.; MOTA, J.C.A. Física do solo: conceitos e aplicações. Fortaleza: Editora Imprensa Universitária, 2008. 290p.

ARGENTA, G.; SILVA, P.R.F.; BORTOLINI, C.G. et al. Relação da leitura do clorofilômetro com os teores de clorofila extraível e de nitrogênio na folha de milho. Revista Brasileira de Fisiologia Vegetal, v.13, n.2, p.158-167, 2001.

BONFIM-SILVA, E.M.; MONTEIRO, F.A.; DA SILVA, T.J.A. Nitrogênio e enxofre na produção e no uso de água pelo capimbraquiária em degradação. Revista Brasileira de Ciência do Solo, v.31, p.309-317, 2007.

BULLOCK, D.G.; ANDERSON, D.S. Evaluation of the Minolta SPAD-502 chlorophyll meter for nitrogen management in corn. Journal of Plant Nutrition, v.21, p.741-755, 1998.

CABRERA-BOSQUET, L.; ALBRIZIO, R.; ARAUS, J.L. et al. Photosynthetic capacity of field-grown durum wheat under different $\mathrm{N}$ availabilities: a comparative study from leaf to canopy. Environmental and Experimental Botany, v.67, n.1, p.145-152, 2009.

COLOZZA, M.T.; KIEHL, J.C.; WERNER, J.A. et al. Respostas de Panicum maximum cultivar Aruana a doses de nitrogênio. Boletim de Indústria Animal, v.57, p.21-32, 2000.

COMISSÃO DE FERTILIDADE DO SOLO DO ESTADO DE MINAS GERAIS - CFSEMG. Recomendações para uso de corretivos e fertilizantes em Minas Gerais - $5^{\mathrm{a}}$ Aproximação. Viçosa, MG: UFV, 1999. 359p.

COSTA, C.; DWYER, L.M.; DUTILLEUL, P. et al. Interrelationships of applied nitrogen, spad, and yield of leafy and non-leafy maize genotypes. Journal of Plant Nutrition, v.24, p.1173-1194, 2001.

COSTA, K.A.P.; FAQUIN, V.; OLIVEIRA, I.P. et al. Doses e fontes de nitrogênio em pastagem de capim-marandu. II - Nutrição nitrogenada da planta. Revista Brasileira de Ciências do Solo, v.32, p.1601-1607, 2008.

GASTAL, F.; BELANGER, G.; LEMAIRE, G.A model of the leaf extension rate of tall fescue in response to nitrogen and temperature. Annals of Botany, v.70, p.437-442, 1992.

GODOY, L.J.G.; BÔAS, R.L.V.; FILHO, H.G. Adubação nitrogenada na cultura do milho baseada na medida do clorofilômetro e no 
índice de suficiência em nitrogênio (ISN). Acta Scientiarum Agronomy, v.25, n.2, p.373-380, 2003.

GODOY, L.J.G.; SOUTO, L.S.; FERNANDES, D.M. et al. Uso do clorofilômetro no manejo da adubação nitrogenada para milho em sucessão a pastagem de Brachiaria decumbens. Ciência Rural, v.37, n.1, p.38-44, 2007.

HOPKINS, W.G. Introduction to plant physiology. 2.ed. New York: John Wiley \& Sons, 1999. 512p.

HUSSAIN, F.; BRONSON, K.F.; YADVINDER-SINGH, B. et al. Use of chlorophyll meter sufficiency indices for nitrogen management of irrigated rice in Asia. Agronomy Journal, v.92, p.875-879, 2000.

KUWAHARA, F.A.; SOUZA, G.M. Fósforo como possível mitigador dos efeitos da deficiência hídrica soobre o crescimento e as trocas gasosas de Brachiaria brizantha cv. MG-5 Vitória. Acta Scientiarum Agronomy, v.31, n.2, p.261-267, 2009.

LAMBERS, H.; CHAPAIN III, F.S.; PONS, T.L. Plant physiological ecology. Berlin: Springer, 1998. 540p

LARCHER, W. Ecofisiologia vegetal. São Carlos: RiMa, 2006. $550 \mathrm{p}$.

MINOLTA CAMERA. Manual for chlorophyll meter SPAD502. Osaka: 1989. 22p.

NEVES, O.S.C.; CARVALHO, J.G.; MARTINS, F.A.D. et al. Uso do SPAD-502 na avaliação dos teores foliares de clorofila, nitrogênio, enxofre, ferro e manganês do algodoeiro herbáceo. Pesquisa Agropecuária Brasileira, v.40, n.5, p.517-521, 2005.

PAN, Y.; HON, J.; JENKINS, J. et al. Importance of foliar nitrogen concentration to predict forest productivity in the MidAtlantic Region. Forest Science, v.50, n.3, p.279-289, 2004.
SANTOS, A.R. Diagnose nutricional e respostas do capim braquiária submetido a doses de nitrogênio e enxofre. 1997. 115f. Tese (Doutorado em Solos e Nutrição de Plantas) Escola Superior de Agricultura "Luiz de Queiroz"/Universidade de São Paulo, Piracicaba.

SCHEPERS, J.S.; FRANCIS, D.D.; VIGIL, M. et al. Comparison of corn leaf nitrogen concentration and chlorophyll meter readings. Communications in Soil Science and Plant Analysis, v.23, p.2173-2187, 1992.

SCHULZE, E.D.; HALL, A.E. Stomatal responses, water loss and $\mathrm{CO}_{2}$ assimilation rates of plants in contrasting enviroments. In: LANGE, O.L.; NOBEL, P.S.; OSMOND, C.B. et al. (Eds.) Physiological plant ecology: II. Water relations and carbon assimilation. Berlin: Spring-Verlag, 1982. p.181-229.

SILVEIRA, P.M.; BRAZ, A.J.B.P.; DIDONET, A.D. Uso do clorofilômetro como indicador da necessidade de adubação nitrogenada em cobertura no feijoeiro. Pesquisa Agropecuária Brasileira, v.38, n.9, p.1083-1087, 2003.

SLATYER, R.O. Plant-water relationships. New York: Academic Press, 1967. 366p.

STATISTICAL ANALYSES SYSTEM - SAS. SAS System for Windows. Version 8.0. Cary: SAS Institute Inc. 2003. (2 CD-ROM)

TAIZ, L.; ZEIGER, E. Fisiologia vegetal. Porto Alegre: Artmed, 2009. 848 p.

YIN, C.; PANG, X.; CHEN, K. The effects of water, nutrient availability and their interaction on the growth, morphology and physiology of two poplar species. Environmental and Experimental Botany, v.67, n.1, p.196-203, 2009. 